\title{
Electrochemical, Photochemical, and Photoelectrochemical Treatment of Sodium $\boldsymbol{p}$-Cumenesulfonate
}

\author{
Lidia Osiewala • Adam Socha • Aleksandra Perek • \\ Marek Socha $\cdot$ Jacek Rynkowski
}

Received: 9 April 2013 / Accepted: 10 July 2013 /Published online: 13 August 2013

(C) The Author(s) 2013. This article is published with open access at Springerlink.com

\begin{abstract}
The degradation of sodium $p$-cumenesulfonate (SCS) by electrochemical, photochemical, and photoelectrochemical methods in aqueous solution of $\mathrm{NaClO}_{4}$, $\mathrm{NaCl}$, and $\mathrm{NaClO}$ has been studied. It was found that as a result of $\mathrm{NaClO}_{4}$ electroreduction and photodecomposition, the ions $\mathrm{Cl}^{-}$and $\mathrm{ClO}_{3}^{-}$are formed. These ions undergo transformations into radicals, mainly $\mathrm{Cl}^{\circ}, \mathrm{Cl}_{2}{ }^{--}$, $\mathrm{ClO}^{-}, \mathrm{ClO}_{2}{ }^{--}$, and $\mathrm{ClO}_{3}{ }^{-}$, due to electrochemical and photochemical reactions. It was shown that the interpretation of results of the studies over mineralization processes carried out in the presence of $\mathrm{ClO}_{4}{ }^{-}$cannot be adequate without taking into consideration the reduction of $\mathrm{ClO}_{4}{ }^{-}$ to $\mathrm{Cl}^{-}$and $\mathrm{ClO}_{3}{ }^{-}$. Therefore, previous works presented in the literature should be rediscussed on the basis of the new data. Photoelectrochemical mineralization of substrate in $\mathrm{NaCl}$ solution at the concentration of $16 \mathrm{mmol} \mathrm{L}^{-1}$ is comparable with the efficiency of the reaction in $\mathrm{NaClO}_{4}$ solution containing more than $8 \mathrm{mmol} \mathrm{L}^{-1}$ of $\mathrm{NaClO}$. Total SCS mineralization was obtained in
\end{abstract}

\footnotetext{
L. Osiewała $(\bowtie) \cdot A$. Socha $\cdot$ A. Perek $\cdot$ J. Rynkowski Lodz University of Technology, Department of General and Ecological Chemistry, Zeromskiego 116, 90-924 Lodz, Poland

e-mail: lidia.osiewala@gmail.com

L. Osiewała

e-mail: lidia.osiewala@edu.p.lodz.pl

A. Socha

e-mail: adam.socha@p.lodz.pl

M. Socha

Galvanic Technology,

Lodowa 101, 93-232 Lodz, Poland
}

the photoelectrochemical reactor with a UV immersion lamp with a power $15 \mathrm{~W}$ in the period of $135 \mathrm{~min}$ and current intensity of $350 \mathrm{~mA}$. In such conditions, the power consumption was about $1.2 \mathrm{kWh}$ per $\mathrm{g}$ of TOC removed.

Keywords Cyclic voltammetry $\cdot \mathrm{NaClO}_{4}$ decomposition $\cdot$ Photoelectrochemical process . Sodium $p$-cumenesulfonate

\section{Introduction}

Hydrotropes are mild surface active amphiphilic organic salts with hydrophobic part comparatively smaller than in the case of conventional surfactant. Hydrotropes exhibit a higher and often more selective ability to solubilization of organic compounds in water. The self-aggregation of the hydrotropes has been considered to be a pre-requisite for a number of applications in various fields such as drugs solubilization (Yalkowsky 1981), chemical reactions (Khadilkar et al. 1995), and separation of organic compounds (Gaikar and Phatak 1999). Hydrotropes are among over 5,000 high production volume chemical substances listed by the Organization for Economic Cooperation and Development (OECD). The consumption of these substances in 2005 reaches ca. 29,000 metric tons in the USA, 17,000 in Europe, and 1,100 in Australia. These compounds are used as additives for household cleaners such as laundry powders and liquids, laundry bleach, dishwashing liquid, toilet cleaners and liquid, powder, gel, and spray surface 
cleaners. The use of hydrotropes in household laundry and cleaning products raises no safety concerns for the consumers. They are also used as corrosion inhibitors, components of electroplating baths, and as a support for an extraction process (Stanton et al. 2010). The studies carried out on individual hydrotropes or surfactant-hydrotrope mixtures support the fact that hydrotropes are able to form self-aggregates in aqueous solutions known as minimum hydrotrope concentration (MHC), analogous to critical micelle concentration (CMC) for surfactants (Bhat and Gaikar 1999; Bhat and Gaikar 2000).

The photoelectrochemical process is an efficient method of degradation of organic pollutants in water (Osiewała et al. 2012; Socha et al. 2005). The effectiveness of this process depends on the composition of supporting electrolyte and electrode properties. There are numerous semiconductors which can be used as photocatalysts: $\mathrm{TiO}, \mathrm{WO}_{3}, \mathrm{SnO}_{2}, \mathrm{ZnO}$, and $\mathrm{CdS}$. As generally observed, $\mathrm{TiO}_{2}$ is an efficient photocatalyst with high quantum yields. Photocatalysis by $\mathrm{TiO}_{2}$ $(\mathrm{Eg}=3.2 \mathrm{eV})$ involves, under UV light excitation, the generation of electron $\left(\mathrm{e}^{-}\right)$in the conduction band and a hole $\left(\mathrm{h}^{+}\right)$in the valence band. These species undergo charge transfer reactions across the interface with oxygen, water, or organic pollutants adsorbed on $\mathrm{TiO}_{2}$ surface. The reaction of $\mathrm{h}^{+}$with $\mathrm{OH}^{-}$or $\mathrm{H}_{2} \mathrm{O}$ leads to the generation of reactive ${ }^{\circ} \mathrm{OH}$ radicals, which are powerful oxidants attacking the recalcitrant organic compounds (Noorjahan et al. 2003); the reaction pathway is illustrated by Eqs. (1)-(6):

Photoexcitation $\mathrm{TiO}_{2}+\mathrm{h} v \rightarrow \mathrm{TiO}_{2}\left(\mathrm{~h}^{+}\right)+\mathrm{TiO}_{2}\left(\mathrm{e}^{-}\right)$

Hole pathway : $\mathrm{OH}^{-}+\mathrm{TiO}_{2}\left(\mathrm{~h}^{+}\right) \rightarrow \mathrm{TiO}_{2}+{ }^{\cdot} \mathrm{OH}$

$\mathrm{H}_{2} \mathrm{O}+\mathrm{TiO}_{2}\left(\mathrm{~h}^{+}\right) \rightarrow \mathrm{TiO}_{2}+\mathrm{H}^{+}+{ }^{\bullet} \mathrm{OH}$

Electron pathway: $\mathrm{TiO}_{2}\left(\mathrm{e}^{-}\right)+\mathrm{O}_{2} \rightarrow \mathrm{TiO}_{2}+\mathrm{O}_{2}{ }^{--}(4)$

$\mathrm{O}_{2}^{\cdot-}+\mathrm{H}^{+} \rightarrow \mathrm{HO}_{2} \cdot$

$\cdot \mathrm{OH}+\mathrm{M} \rightarrow$ degradation products

The electrocatalytic activity of $\mathrm{RuO}_{2}$ coupled with oxygen evolution is very favorable for the photochemical process of pollutants degradation, because the oxygen superoxide anion radicals $\left(\mathrm{O}_{2}{ }^{-}\right)$formed during the photochemical process can produce additional amounts of hydroxyl radicals (Pelegrini et al. 1999).

The dissolved oxygen molecule absorbs the quantum of UV light forming activated oxygen radicals. Subsequently, the oxygen radical reacts with hydrogen ions to produce water. At the same time, activated oxygen radicals can also be destroyed by single radical termination as a result of collision with inert water (Harano and Shmit 1968), Eqs. (7)-(9):

$\mathrm{O}_{2}+\mathrm{hv} \rightarrow 2 \mathrm{O}^{\circ}$

$\mathrm{O}^{\bullet}+\mathrm{H}^{+} \rightarrow \mathrm{H}_{2} \mathrm{O}$

$\mathrm{O}^{\bullet}+\mathrm{H}_{2} \mathrm{O} \rightarrow \frac{1 / 2}{2} \mathrm{O}_{2}+\mathrm{H}_{2} \mathrm{O}$

It has been known that degradation of organic pollutants by UV light radiation is more effective in the presence of some oxidants such as sodium hypochlorite and sodium persulfate (Hepel and Luo 2001; Catanho et al. 2006). One of the most often used hydrotrope is sodium $p$-cumenesulfonate (SCS). The structure of this compound is presented in Fig. 1.

So far, the literature data concerning the degradations of SCS are not numerous. Kimura and Ogata (1983) studied the decomposition of SCS by the photochemical oxidation (UV light $\lambda>290 \mathrm{~nm}$ ) in alkaline aqueous solution with an addition of sodium hypochlorite $(\mathrm{NaClO})$. The SCS mineralization was about $38 \%$ after $45 \mathrm{~min}$ reaction at room temperature and the following products were detected: cumene, 2-isopropylphenol, 4isopropylphenol, and 2-phenyl-2-propanol.

SCS very often coexists in wastewater with chloride ions, for example in zinc electroplating baths (Kozłowski et al. 1990). In many studies, the effect of chloride ions on the photoelectrochemical degradation of pollutants was

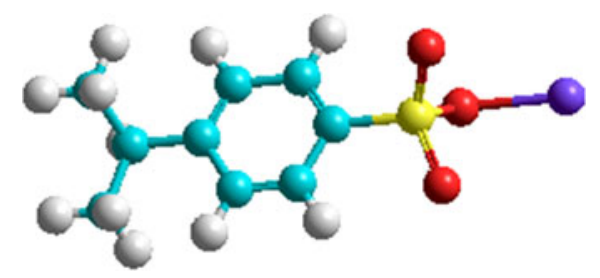

Fig. 1 Scheme of sodium $p$-cumenesulfonate (SCS) 
investigated. Xiao et al. (2009) found that the presence of chlorides accelerates degradation of organic compounds in wastewater.

This work presents the results of sodium $p$ cumenesulfonate degradation in the solutions of $\mathrm{NaClO}_{4}$, $\mathrm{NaCl}$, and the mixtures of $\mathrm{NaClO}_{4}$ and $\mathrm{NaClO}$ or $\mathrm{NaCl}$ using electrochemical, photochemical, and photoelectrochemical methods.

\section{Materials and Methods}

2.1 Reagents

- Purified water (double purification using Millipore Milli-Q Plus system)

- Sodium $p$-cumenesulfonate, purity $93 \%$ (Huntsman Holland BV, The Netherlands)

- Sodium perchlorate, purity $99 \%$ (Sigma-Aldrich)

- Sodium chloride $(\mathrm{NaCl})$, sodium hypochlorite $(\mathrm{NaClO})$, sodium chlorate $\left(\mathrm{NaClO}_{3}\right)$, and sodium perchlorate $\left(\mathrm{NaClO}_{4}\right)$, purity $99 \%$ (Chempur, Poland)

- Standards for the analysis: sodium hydrogen carbonate $\left(\mathrm{NaHCO}_{3}\right)$, sodium carbonate $\left(\mathrm{Na}_{2} \mathrm{CO}_{3}\right)$, and sodium acetate $\left(\mathrm{CH}_{3} \mathrm{COONa}\right)$ - (Metrohm Poland).

\subsection{Analytical Methods}

In order to assess the mechanism of electrochemical oxidation and reduction of SCS, the cyclic (CV) and differential pulse (DPV) voltammetry measurements were carried out using an Autolab Potentiostat PGstat30 (EcoChemie, Holland). A three-electrode cell was applied in all experiments; platinum and titanium covered with $\mathrm{TiO}_{2}(70 \%)$ and $\mathrm{RuO}_{2}(30 \%)$ electrodes were used as a working electrodes for the oxidation process. The mercury electrode was used as a working electrode for the reduction process. The potential of the working electrode was measured vs. the saturated calomel electrode (SCE), whose standard potential is defined as $0.244 \mathrm{~V}$ vs. the standard hydrogen electrode (SHE). Before the measurements, solutions were purged with argon in order to remove dissolved oxygen. During measurements, an argon blanket was kept over solutions.

Differential capacity was measured using the method of electrochemical impedance spectroscopy (module FRA in Autolab, PGstat30). Electrode potential was changed every $10 \mathrm{mV}$ in the applied potential range. Each measurement was taken on a new drop.

Electrochemical degradation was carried out in an electrochemical cell (reactor volume of $80 \mathrm{~mL}$ ) using electrodes; titanium covered by $\mathrm{TiO}_{2}(70 \%)$ and $\mathrm{RuO}_{2}$ $(30 \%)$ as an anode $(50 \mathrm{~mm} \times 20 \mathrm{~mm})$ and platinum as a cathode $(50 \mathrm{~mm} \times 20 \mathrm{~mm})$. Photoelectrochemical reactions were carried out using the same cell as used in electrochemical reactions insert into two different reactors: first one the reactor RPR 200 (Southern New England Ultraviolet Co.) which was equipped with 16 lamps emitting radiation at the wavelength of $254 \mathrm{~nm}$ (volume $80 \mathrm{~mL}$ ) and second one Labor-UV-Reactor system with volume of $160 \mathrm{~mL}$ (Heraeus Noblelight) equipped with a UV lamp emitting wavelength of $254 \mathrm{~nm}$ and power $15 \mathrm{~W}$ (Fig. 2). The latter reactor was also used in photochemical reactions.

In order to assess the degradation of SCS, the following analytical methods were performed:

Total organic carbon (TOC) was analyzed using TOC 5050A Shimadzu Total Organic Carbon Analyzer, SCS mineralization calculated by Eq. (10):

$\alpha \mathrm{TOC}=\left(\frac{\mathrm{C}_{0}-\mathrm{C}}{\mathrm{C}_{0}}\right) 100$

Where $\alpha$ TOC is TOC conversion (\%), $\mathrm{C}_{0}$ is organic carbon content in initial solution $\left(\mathrm{mg} \mathrm{L}^{-1}\right)$, and $\mathrm{C}$ is organic carbon content in solution after reaction $\left(\mathrm{mg} \mathrm{L}^{-1}\right)$.

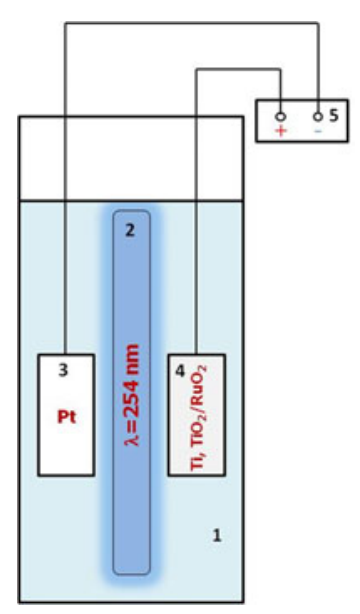

Fig. 2 Schematic diagram of laboratory-scale reactor system: 1 -reactor $V=160 \mathrm{~mL}, 2$ - UV lamp, $\lambda=254 \mathrm{~nm}(15 \mathrm{~W})$, 3-cathode $\mathrm{Pt}$, 4-anode $\mathrm{Ti} / \mathrm{TiO}_{2}$ (70 \%), $\mathrm{RuO}_{2}$ (30\%), 5 - power supply 
UV/Vis spectra were recorded in the wavelength range from 190 to $800 \mathrm{~nm}$ using UV/Vis Spectrophotometer Shimadzu UV-24001 PC.

Sulfate ion concentration was analyzed by means of high performance ion chromatography (HPIC), using Methorm apparatus equipped with a column (Metrosep A Supp 3-250/4.6). The mobile phase contained acetone $(50 \%)$ and water solution $(50 \%)$ of sodium hydrogen carbonate $\left(4 \mathrm{mmol} \mathrm{L}^{-1}\right)$ and sodium carbonate $\left(1 \mathrm{mmol} \mathrm{L}^{-1}\right)$.

The total organic carbon (TOC), UV/Vis spectra, and sulfate ion concentration in the solutions were recorded before and after the process.

\section{Results and Discussion}

\subsection{Electrooxidation and Electroreduction}

The electrooxidation and electroreduction reactions of SCS at the platinum and mercury electrode were studied by cyclic and differential pulse voltammetry in $\mathrm{NaClO}_{4}$ solution. Differential pulse voltammetry is the method with higher resolution, which enables better separation of peaks characterizing subsequent steps of the electrode reaction. Half-wave potential $\left(E_{1 / 2}\right)$ corresponds to the potential of the peak occurring in a differential pulse curve and is characteristic for each of the subsequent steps of the investigated electrode reaction. Basic information about the course of electrochemical reaction is provided by the dependence of the current on the potential.

Figure $3 \mathrm{a}$ shows the reduction of SCS on the mercury electrode. The process starts at a potential of about $-0.8 \mathrm{~V}$ and three peaks are observed during polarization with scan rate $100 \mathrm{mV} \mathrm{s}^{-1}$ in the negative direction at potentials of -1.19 (week), -1.35 , and $-1.45 \mathrm{~V}$. An increase in the scan rate leads to an increase in the peak's maximum current in all cases. Peaks I and III are irreversible, whereas peak II is quasi-reversible and corresponds to the adsorptiondesorption process. A shift of peak I towards the more positive potential and the shift of peak III towards more negative potential are observed. For the last peak, the dependence of current vs. root of scan rate $\left(\mathrm{v}^{1 / 2}\right)$ was determined (insert, Fig. 3a), it is linear and crosses the origin of coordinates. This indicates that the last process (peak III) is characterized by diffusion process. In order to confirm the above results, the changes of double layer capacity for SCS and electrolyte, as well as differential
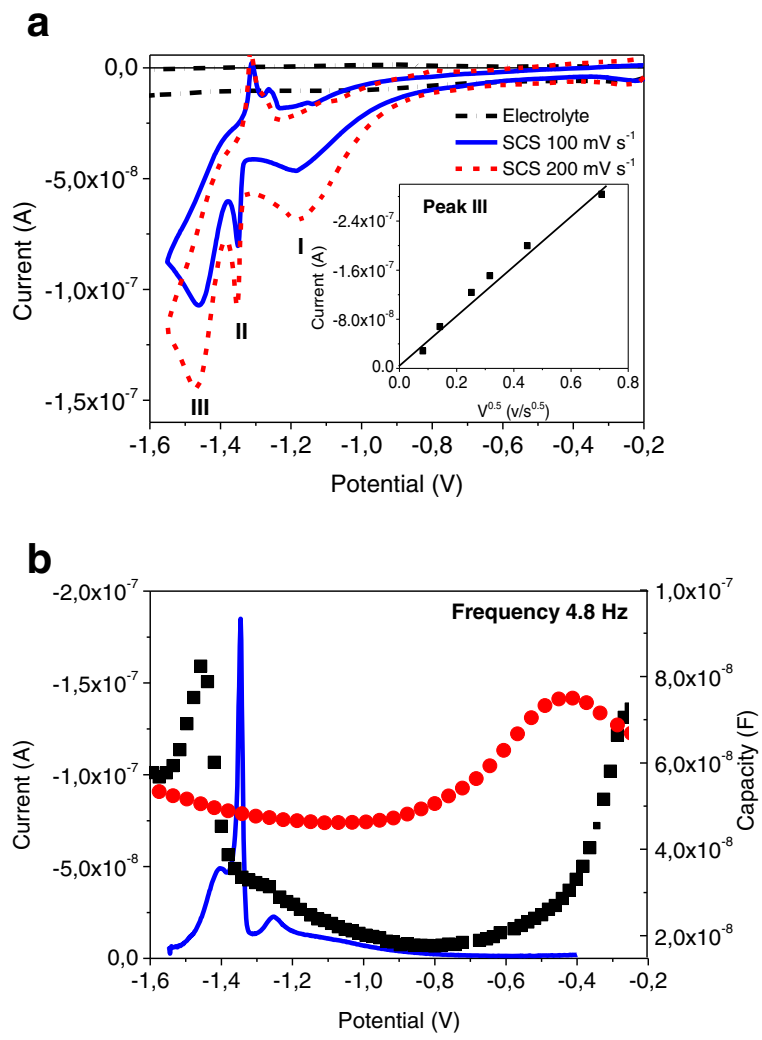

Fig. 3 a Cyclic voltammograms of SCS $\left(50 \mathrm{mmol} \mathrm{L}^{-1}\right)$ in $\mathrm{NaClO}_{4}$ solution $\left(100 \mathrm{mmol} \mathrm{L}^{-1}\right)$, insert; dependence of peak III current $\left(\mathrm{i}_{\mathrm{p}}\right)$ on the square root of the potential scan rate $\left(\mathrm{v}^{1 / 2}\right)$. b Differential pulse voltamogram of $(-) \mathrm{SCS}\left(40 \mathrm{mmol} \mathrm{L}^{-1}\right)$ in $\mathrm{NaClO}_{4}$ solution $\left(100 \mathrm{mmol} \mathrm{L}^{-1}\right)$, capacity vs. the potential of $\mathrm{SCS}$ $\left(40 \mathrm{mmol} \mathrm{L}^{-1}\right)$ in $\mathrm{NaClO}_{4}$ solution $\left(100 \mathrm{mmol} \mathrm{L}^{-1}\right)$, and $\bullet \mathrm{NaClO}_{4}$ solution $\left(100 \mathrm{mmol} \mathrm{L}^{-1}\right)$, recorded at mercury electrode, $\mathrm{pH}=7$

pulse voltammograms, were recorded (Fig. 3b). In the potential range from -0.2 to $-1.39 \mathrm{~V}$, the double layer capacity is lower in the solution containing SCS and electrolyte compared to the solution without substrate. Lower capacity corresponds to the adsorption of substrate and reaction products on the electrode's surface. A sharp desorption-adsorption peak in cyclic voltammogram (Fig. 3a), the differential pulse voltammogram, and the increase in capacity (Fig. 3b) indicate that substrate and reaction products undergo desorption from the electrode surface (at the potential of $-1.35 \mathrm{~V}$ ), and therefore, the diffusion peak (III) may arise.

The substrate was also oxidized at platinum and titanium covered by $\mathrm{TiO}_{2}(70 \%)$ and $\mathrm{RuO}_{2}(30 \%)$ electrodes, but peaks were not observed at cyclic and differential pulse voltammograms in the potential range lower than the potential at which oxygen evolution started. Therefore, 
the dependence of current on the potential on platinum electrode in the saturated solution of SCS in acetonitryle in the presence of sodium tetrabuthylammonium perchlorate as a basic electrolyte was observed. The potential was measured versus the ferrocene and saturated calomel electrodes. The dependence presented in Fig. 4 proves that oxidation of the substrate begins with the potential of $1.7 \mathrm{~V}$, and two stages of oxidation characterized by poorly shaped peaks were observed on the curves.

The curves of capacity vs. potential were obtained for both electrodes (Fig. 5a, b). In both cases in the potential range from 0.2 to $1.2 \mathrm{~V}$, the double layer capacity is lower in the solution containing SCS and electrolyte than in the solution without substrate; this indicates that SCS was adsorbed on the electrode surface in the investigated potential range.

The above results indicate that the reduction of SCS starts at the potential of $-0.8 \mathrm{~V}$ vs. SCE and an oxidation at the potential of $1.7 \mathrm{~V}$; however, the oxidation potential of SCS is higher than the potential of oxygen evolution. The current density used in the electrochemical treatment was tenfold higher than it followed from the cyclic voltammograms (from $5 \times 10^{-3} \mathrm{~A} \mathrm{~cm}^{-2}$ to $\left.1.5 \times 10^{-2} \mathrm{~A} \mathrm{~cm}^{-2}\right)$. The electrochemical process in water can generate hydroxyl radicals $\left({ }^{\circ} \mathrm{OH}\right)$. The direct evidence for ${ }^{\circ} \mathrm{OH}$ formation was obtained by the electron spin resonance method (YanQing et al. 2007). The powerful ${ }^{\circ} \mathrm{OH}$ generated electrochemically could effectively degrade organic pollutants, but during the electrochemical degradation of SCS only slight change of

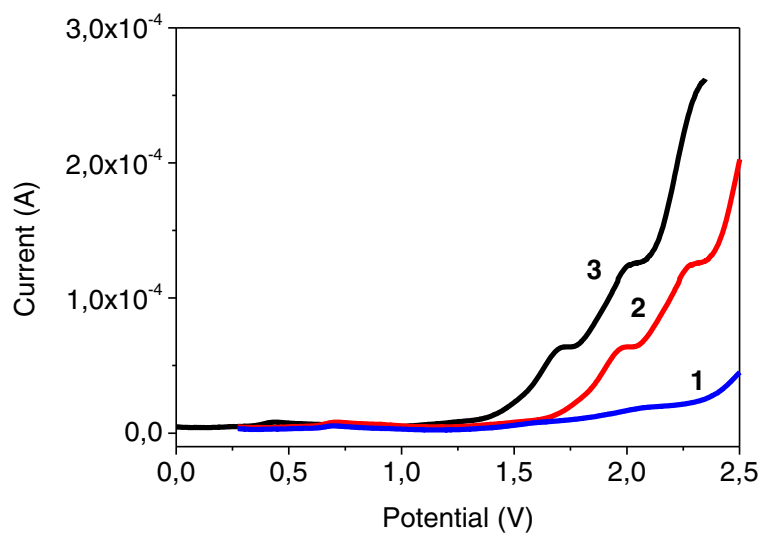

Fig. 4 Differential pulse voltammograms: curve 1-electrolyte: sodium tetrabutyloamoniumperchlorate (TBAP; $100 \mathrm{mmol} \mathrm{L}^{-1}$ ) in acetonitrile measured versus ferrocene electrode $\left([\mathrm{Fc}]^{+} /[\mathrm{Fc}]\right)$, SCS (saturated solution) and TBAP $\left(100 \mathrm{mmol} \mathrm{L}^{-1}\right)$ in acetonitrile measured versus curve 2-saturated calomel electrode (SCE) and curve 3 -ferrocene electrode ( $\left.[\mathrm{Fc}]^{+} /[\mathrm{Fc}]\right), \mathrm{pH}=7$
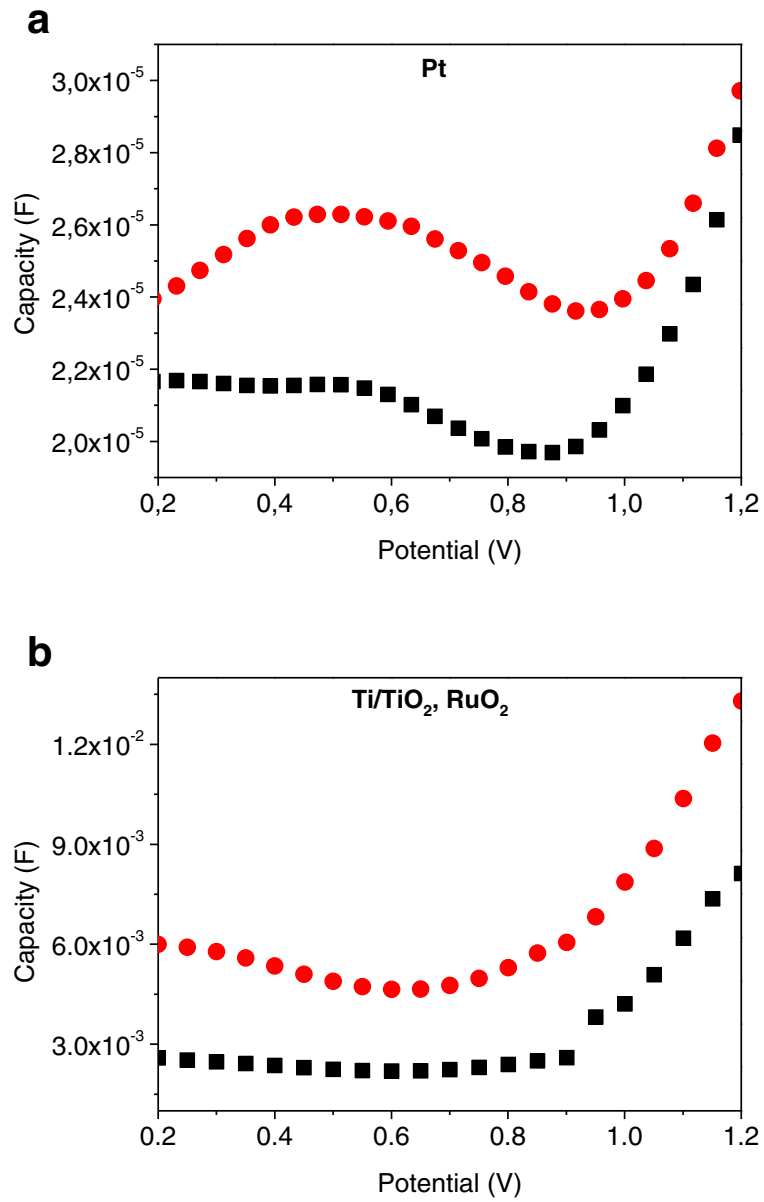

Fig. 5 The change of capacity vs. potential of $\square$ SCS $\left(40 \mathrm{mmol} \mathrm{L}^{-1}\right)$ in $\mathrm{NaClO}_{4}$ solution $\left(100 \mathrm{mmol} \mathrm{L}^{-1}\right)$ and $\bullet$ $\mathrm{NaClO}_{4}$ solution $\left(100 \mathrm{mmol} \mathrm{L}^{-1}\right.$; frequency of $\left.24.6 \mathrm{~Hz}, \mathrm{pH}=7\right)$; $\mathbf{a}$ at platinum electrode and $\mathbf{b}$ at $\mathrm{Ti} / \mathrm{TiO}_{2}(70 \%)$ and $\mathrm{RuO}_{2}(30 \%)$ electrode

$\alpha$ TOC about $5 \%$ was observed. It may be caused by the strong adsorption of substrate on the electrode surface, which is associated with the generation of hydroxyl radicals.

\subsection{Photochemical Mineralization}

Photochemical degradation of SCS $\left(2 \mathrm{mmol} \mathrm{L}^{-1}\right)$ was carried out in three aqueous solutions: $\mathrm{NaClO}_{4}$, $\mathrm{NaClO}_{4}+\mathrm{NaClO}$ and $\mathrm{NaCl}$. In all cases, after a 120 min reaction, SCS was degraded, about $40 \%$ sulfate groups was disconnected from the aromatic ring, and $\alpha \mathrm{TOC}$ was in the range from $7 \%$ to $10 \%$. Exemplary results of photochemical SCS degradation in $\mathrm{NaClO}_{4}$ solution are presented in Fig. 6. 


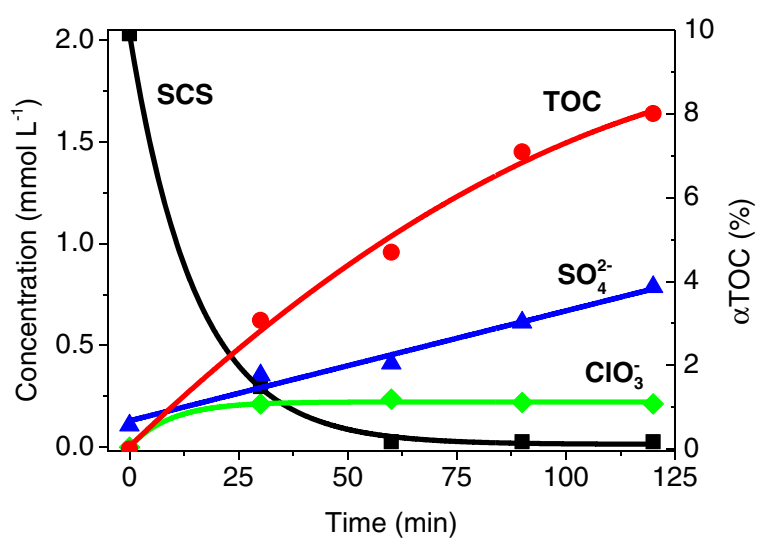

Fig. 6 The change of the concentration of $\mathrm{SCS}, \mathrm{SO}_{4}{ }^{2-}, \mathrm{ClO}_{3}{ }^{-}$ (left axis), and $\alpha \mathrm{TOC}$ (right axis) vs. time of photochemical reaction of SCS $\left(2 \mathrm{mmol} \mathrm{L} \mathrm{L}^{-1}\right)$ in $\mathrm{NaClO}_{4}$ solution (100 $\mathrm{mmol} \mathrm{L}^{-1}$ ), $V=160 \mathrm{~mL}$ and UV lamp $15 \mathrm{~W}, \lambda=254 \mathrm{~nm}$

In order to improve the degradation of SCS, electrochemical and photochemical methods were combined.

\subsection{Photoelectrochemical Mineralization}

UV light and chlorination are two of the most common disinfection methods of water and wastewater. Hypochlorite acid can form hydroxyl and hypochlorite radicals by irradiation with UV light in the range from 200 to $400 \mathrm{~nm}$ (Xiao et al. 2009).

During the electrolysis of the solutions containing chloride ions the following reactions may occur Eqs. (11)-(16):

Anode:

$2 \mathrm{Cl}^{-} \rightarrow \mathrm{Cl}_{2}+2 \mathrm{e}^{-}$

$4 \mathrm{OH}^{-} \rightarrow \mathrm{O}_{2}+\mathrm{H}_{2} \mathrm{O}+4 \mathrm{e}^{-}$

Cathode:

$2 \mathrm{H}_{2} \mathrm{O}+2 \mathrm{e}^{-} \rightarrow \mathrm{H}_{2}+2 \mathrm{OH}^{-}$

$\mathrm{Cl}_{2}+2 \mathrm{e}^{-} \rightarrow 2 \mathrm{Cl}^{-}$

Bulk of the solution

$\mathrm{Cl}_{2}+\mathrm{H}_{2} \mathrm{O} \rightarrow \mathrm{HClO}+\mathrm{HCl}$

$3 \mathrm{ClO}^{-}+3 \mathrm{H}_{2} \mathrm{O} \rightarrow 3 \mathrm{Cl}^{-}+6 \mathrm{OH}^{-}$

Some researchers have reported that hypochlorous acid can dissociate to hydroxyl radical $\left({ }^{\circ} \mathrm{OH}\right)$ and chloride radical $\left(\mathrm{Cl}^{\circ}\right)$ upon adsorption of UV photon in the region 200-400 nm (Guo 1993; Mollna et al. 1980). During radiation the solution at the wavelength of $254 \mathrm{~nm}$, the following reactions may occur, Eqs. (17)-(19):

$\mathrm{HClO}+\mathrm{h} v \rightarrow{ }^{\circ} \mathrm{OH}+\mathrm{Cl}^{\circ}$

$\mathrm{ClO}^{-}+\mathrm{h} v \rightarrow \mathrm{O}^{\cdot-}+\mathrm{Cl}^{\circ}$

$\mathrm{Cl}_{2}+\mathrm{h} v \rightarrow 2 \mathrm{Cl}^{\bullet}$

The reaction of ${ }^{\circ} \mathrm{OH}$ with $\mathrm{Cl}^{-}$in the acidic solution leads to a rapid formation of $\mathrm{Cl}_{2}{ }^{--}$and can be formulated as follows, Eqs. (20)-(21):

$\mathrm{HClO}^{\cdot-}+\mathrm{H}+\rightarrow \mathrm{H}_{2} \mathrm{O}+\mathrm{Cl}^{\bullet}$

$\mathrm{Cl}^{\bullet}+\mathrm{Cl}^{-} \rightleftarrows \mathrm{Cl}_{2}^{-}$

The radicals ${ }^{\circ} \mathrm{OH}, \mathrm{Cl}^{\circ}$, and $\mathrm{Cl}_{2}{ }^{--}$are a reactive species which may oxidize many organic compounds. (Hasegawa and Neta 1978; Feng et al. 2007).

Electrochemical and photoelectrochemical studies of oxidation and reduction of organic compounds are often performed in $\mathrm{NaClO}_{4}$ aqueous solution as a basic electrolyte. Kim and Anderson (1994) observed that the presence of $\mathrm{ClO}_{4}{ }^{-}$ions in solution significantly slows down the reaction of photocatalytic oxidation of formic acid. The degradation degree was much higher in the solution without an addition of $\mathrm{ClO}_{4}{ }^{-}$ions. In the work of Zhang et al. (2005), it was observed that during the photochemical and photoelectrocatalytic oxidation of the reactive Brillant Orange K-R, the presence of $\mathrm{ClO}_{4}{ }^{-}$ions lowers the rate of degradation of the compound, whereas the presence of $\mathrm{Cl}^{-}$ions considerably improves the efficiency of the reaction, particularly at higher concentrations of chloride ions.

\subsection{Photoelectrochemical Treatment of SCS in Rayonet Photoreactor}

Due to a different assessment of the influence of $\mathrm{NaClO}_{4}$ on the effect of photochemical and photoelectrochemical reactions, the studies of SCS degradation in four different solutions containing: $\mathrm{NaClO}_{4}\left(100 \mathrm{mmol} \mathrm{L}{ }^{-1}\right), \mathrm{NaClO}_{4}$ $\left(100 \mathrm{mmol} \mathrm{L}^{-1}\right)$ with the addition of $\mathrm{NaClO}$ or $\mathrm{NaCl}$ in the concentration range from 0 to $16 \mathrm{mmol} \mathrm{L}^{-1}$, and $\mathrm{NaCl}$ in the concentration range from 2 to $16 \mathrm{mmol} \mathrm{L}^{-1}$ were 
performed. The studies were carried out in an electrolyzer placed in the photoreactor containing 16 lamps emitting radiation at the wavelength of $254 \mathrm{~nm}$, the solution volume was $80 \mathrm{~mL}$ and current intensity of $0.3 \mathrm{~A}$.

Figure 7 shows the dependence of changes of SCS and $\mathrm{SO}_{4}{ }^{-2}$ concentrations as well as $\alpha \mathrm{TOC}$ during the photoelectrochemical reaction in $\mathrm{NaClO}_{4}(100 \mathrm{mmol}$ $\mathrm{L}^{-1}$ ) solution. This dependence proves that after the first $180 \mathrm{~min}$, the substrate is practically absent in the solution while the concentration of $\mathrm{SO}_{4}{ }^{2-}$ ions increases to $1.1 \mathrm{mmol} \mathrm{L}^{-1}$ which corresponds with about $55 \%$ loss of the substrate. That indicates the formation of other products containing the sulfonic group. The concentration of $\mathrm{SO}_{4}{ }^{2-}$ ions, as a product of desulfonation grows linearly and is about three times higher than lowering the $\alpha \mathrm{TOC}$ value. After $300 \mathrm{~min}$ of the reaction, $93 \%$ desulfonation of the substrate and $35 \%$ decrease in $\alpha \mathrm{TOC}$ were observed. It proves an almost complete desulfonation of the substrate and other containing sulfur reaction products as well as the formation in the solution of organic compounds free from sulfur, which oxidize harder than the substrate. It is worth remembering that in electrochemical and photochemical reaction in $\mathrm{NaClO}_{4}$ solution $\left(100 \mathrm{mmol} \mathrm{L}^{-1}\right)$ the substrate undergoes the mineralization in $5 \%$ and $8 \%$, respectively, whereas in the photoelectrochemical reaction the mineralization increases to $35 \%$. It indicates that apart from the additive effect of both reactions, the following factors may influence the increase in mineralization: generating photocurrent, easier oxidation of possibly excited substrate, the photocatalytic effect of electrode and the formation of

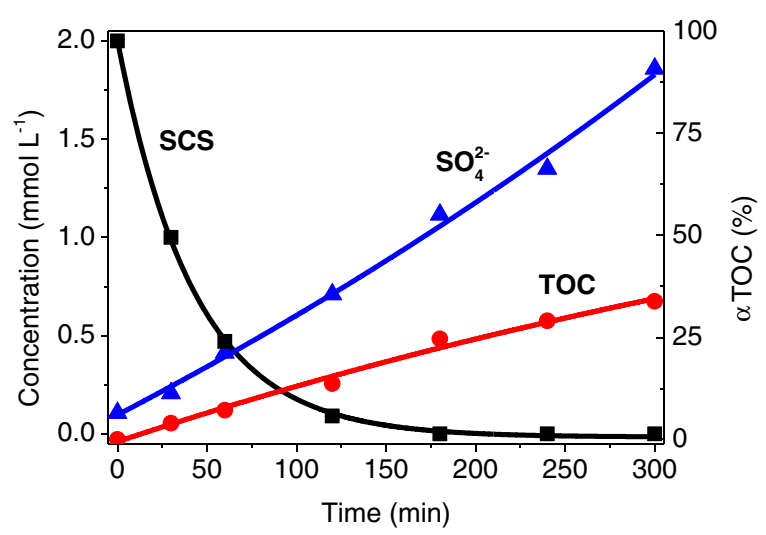

Fig. 7 The change of the concentration of $\mathrm{SCS}, \mathrm{SO}_{4}{ }^{2-}$ (left axis) and $\alpha \mathrm{TOC}$ (right axis) vs. time of photoelectrochemical reaction of SCS $\left(2 \mathrm{mmol} \mathrm{L}^{-1}\right)$ in $\mathrm{NaClO}_{4}$ solution $\left(100 \mathrm{mmol} \mathrm{L}^{-1}\right)$, $V=80 \mathrm{~mL}, 16 \mathrm{UV}$ lamps, $\lambda=254 \mathrm{~nm}$, current intensity of $0.3 \mathrm{~A}$, $\mathrm{pH}=7$ oxidants. During the electrochemical reaction in $\mathrm{NaClO}_{4}$ solution oxygen and ${ }^{\circ} \mathrm{OH}$ radicals are formed. Hydroxyl and $\mathrm{O}^{--}$radicals resulting from the radiation of molecular $\mathrm{O}_{2}$ in an inert environment have the oxidation potential $1.8 \mathrm{~V}$ vs. NHE, while in the acidic environment the oxidation potential of ${ }^{\circ} \mathrm{OH}$ radicals is $2.7 \mathrm{~V}$ vs. NHE. During the photoelectrochemical reaction of SCS in $\mathrm{NaClO}_{4}\left(100 \mathrm{mmol} \mathrm{L}{ }^{-1}\right)$, after about $60 \mathrm{~min} \mathrm{pH}$ of the solution decreases systematically from the value of 7.5 to about 3.5 after $300 \mathrm{~min}$ of the reaction. This suggests that if a sufficient number of hydroxyl radicals were formed, an increase in the mineralization should be observed along with the decrease of $\mathrm{pH}$. However, it is not confirmed by the dependence of $\alpha \mathrm{TOC}$ on the reaction time.

The above analysis shows that during the photoelectrochemical reaction of SCS in $\mathrm{NaClO}_{4}\left(100 \mathrm{mmol} \mathrm{L}^{-1}\right)$ not sufficient amount of oxidants with a higher than $1.8 \mathrm{~V}$ potential allowing a complete mineralization of the substrate is formed. Therefore, the experiments of the photoelectrochemical reaction of SCS in $\mathrm{NaClO}_{4}(100 \mathrm{mmol}$ $\mathrm{L}^{-1}$ ) solutions, containing different concentrations of $\mathrm{NaClO}$ or $\mathrm{NaCl}$ (from 0 to $16 \mathrm{mmol} \mathrm{L}^{-1}$ ) and in monocomponent $\mathrm{NaCl}$ solution (from 2 to $16 \mathrm{mmol}$ $\mathrm{L}^{-1}$ ) were carried out. The reaction time was $120 \mathrm{~min}$. The results are presented in Fig. 8.

In $\left(\mathrm{NaClO}_{4}+\mathrm{NaCl}\right)$ solution (curve 3 ) along with the increase in concentration of chloride ions, an almost

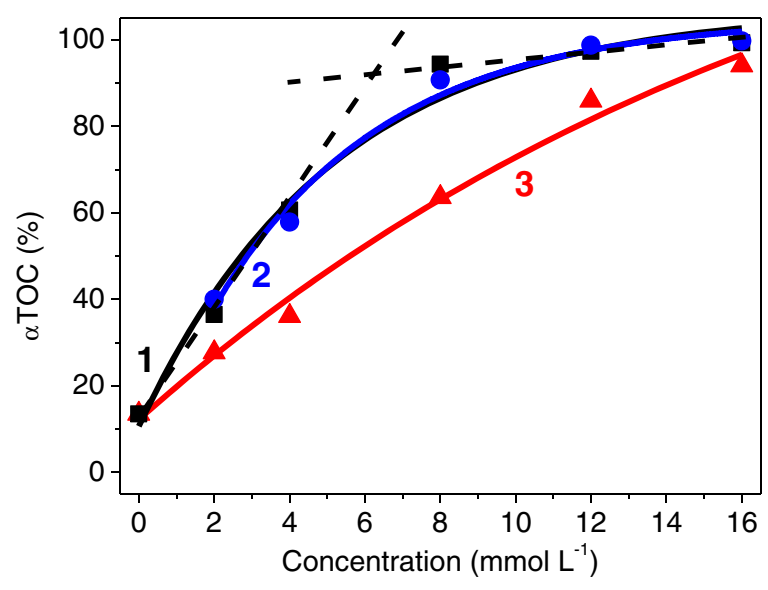

Fig. 8 The change of $\alpha$ TOC vs. concentration of additives using in photoelectrochemical reaction of SCS $\left(2 \mathrm{mmol} \mathrm{L}^{-1}\right)$ : curve 1 (ם) - $\mathrm{NaClO} \quad\left(0-16 \quad \mathrm{mmol} \mathrm{L}^{-1}\right)$ in $\mathrm{NaClO}_{4}$ solution (100 mmol L $\left.{ }^{-1}\right)$, curve $2(\bullet)-\mathrm{NaCl}$ solution $\left(2-16 \mathrm{mmol} \mathrm{L}^{-1}\right)$, and curve $3(\mathbf{\Lambda})-\mathrm{NaCl}\left(0-16 \mathrm{mmol} \mathrm{L}^{-1}\right) \mathrm{NaClO}_{4}$ solution $\left(100 \mathrm{mmol} \mathrm{L}{ }^{-1}\right)$, time $=120 \mathrm{~min}, V=80 \mathrm{~mL}, 16 \mathrm{UV}$ lamps, $\lambda=254 \mathrm{~nm}$, current intensity of $0.3 \mathrm{~A}, \mathrm{pH}=7$ 
linear increase in $\alpha$ TOC up to about $90 \%$ at $\mathrm{Cl}^{-}$of $16 \mathrm{mmol} \mathrm{L}{ }^{-1}$ is observed. In the case of $\left(\mathrm{NaClO}_{4}+\right.$ $\mathrm{NaClO}$ ) solution (curve 1) two ranges of increase in $\alpha$ TOC can be distinguished depending on the concentration of $\mathrm{ClO}^{-}$ions: a relatively sharp within the concentration range from 0 to $6 \mathrm{mmol} \mathrm{L}^{-1}$ and much lower in the range from 6 to $16 \mathrm{mmol} \mathrm{L}^{-1}$. The changes of $\alpha \mathrm{TOC}$ during the SCS reaction in the $\mathrm{NaCl}$ solution (curve 2) are the same as in $\left(\mathrm{NaClO}_{4}+\mathrm{NaClO}\right)$ mixture.

SCS degradation in $\mathrm{NaClO}_{4}$ solution with an addition of $\mathrm{Cl}^{-}$ions is accelerated in comparison to the reaction rate in $\mathrm{NaClO}_{4}$ itself due to the formation on the anode gaseous chlorine and its chemical and photochemical transformations. However, the amount of $\mathrm{Cl}_{2}$ formed depends on the concentration of $\mathrm{Cl}^{-}$and $\mathrm{ClO}_{4}{ }^{-}$ions deactivating the surface of the anode. It is well known that $\mathrm{ClO}_{4}{ }^{-}$oxidizes to $\mathrm{ClO}_{4}$ and takes up an active site on the surface of $\mathrm{Ti} / \mathrm{TiO}_{2}$ as follows:

$\mathrm{ClO}_{4}^{-}+\mathrm{h}^{+} \rightarrow \mathrm{ClO}_{4}$

The electrons occupy the vacancies in the valence band of $\mathrm{TiO}_{2}$ left by the electrons which have been excited to the conduction band of $\mathrm{TiO}_{2}$. Such processes will be repeated upon the illumination of the cell (Rahman et al. 2007).

Practically the linear dependence of the $\alpha$ TOC on the reaction time in $\mathrm{NaClO}_{4}$ solution and the proportional increase in $\alpha \mathrm{TOC}$ with the increase in the concentration of chloride ions in $\mathrm{NaClO}_{4}$ solution suggests that oxidation of the substrate in monocomponent $\mathrm{NaClO}_{4}$ solution can be basically caused by radicals formed from the products of $\mathrm{NaClO}_{4}$ electrochemical reduction and photodecomposition.

To summarize, the discussed results indicate that the efficiency of SCS degradation in each of the considered cases is mainly connected with the $\mathrm{Cl}^{\circ}$ and $\mathrm{Cl}_{2}{ }^{\circ}$ radicals formed from the products of electrochemical, chemical and photochemical reactions of the basic electrolyte and $\mathrm{Cl}^{-}$and $\mathrm{ClO}^{-}$ions added. According to Brown (1986) the perchlorate ion is electrochemically reduced to the chloride ion at an active titanium electrode in aqueous solutions. Negative current values can be observed on the positive sweep in the potential range from 200 to $700 \mathrm{mV}$.

Therefore, further studies of SCS degradation in a photoelectrochemical reactor with an immersion lamp in the solutions: $\mathrm{NaClO}_{4}\left(100 \mathrm{mmol} \mathrm{L}^{-1}\right), \mathrm{NaClO}_{4}$ $\left(100 \mathrm{mmol} \mathrm{L}^{-1}\right)$ with the addition of $\mathrm{NaClO}(2 \mathrm{mmol}$ $\left.\mathrm{L}^{-1}\right)$, and $\mathrm{NaCl}\left(16 \mathrm{mmol} \mathrm{L}^{-1}\right)$ were performed.
Additionally, the products of electroreduction, photodestruction, and photoelectrochemical changes of the electrolyte were analyzed.

3.5 Photoelectrochemical Treatment of SCS in Heraeus Photoreactor

Due to the increase in the rate of the substrate destruction in the presence of $\mathrm{Cl}^{-}$and $\mathrm{ClO}^{-}$ions, the studies of photoelectrochemical degradation of SCS were carried out for a larger volume of solution $(160 \mathrm{~mL})$ in the reactor with an immersion mercury lamp. The measurements were taken in the following solutions: $\mathrm{NaClO}_{4}(100 \mathrm{mmol}$ $\left.\mathrm{L}^{-1}\right), \mathrm{NaClO}_{4}$ containing $\mathrm{NaClO}\left(2 \mathrm{mmol} \mathrm{L}^{-1}, \mathrm{NaClO}\right.$ to $\mathrm{SCS}$ ratio $1: 1)$ and $\mathrm{NaCl}\left(16 \mathrm{mmol} \mathrm{L}^{-1}\right)$. In the reaction products, TOC and the concentration of $\mathrm{SCS}, \mathrm{SO}_{4}{ }^{2-}$, and $\mathrm{ClO}_{3}{ }^{-}$ions were analyzed.

Due to the comparable effect of SCS mineralization in $\mathrm{NaCl}$ and $\left(\mathrm{NaClO}_{4}+\mathrm{NaClO}\right)$ solutions, at the current intensity of $0.3 \mathrm{~A}$, the measurements of the influence of the current intensity in the range from 0.1 to $0.45 \mathrm{~A}$ on the effect of degradation of the substrate in $\mathrm{NaCl}(16 \mathrm{mmol}$ $\mathrm{L}^{-1}$ ) solution were taken. Figure 9 shows $\alpha \mathrm{TOC}$ vs. current intensity during photoelectrochemical degradation of SCS $\left(2 \mathrm{mmol} \mathrm{L}^{-1}\right)$ in $\mathrm{NaCl}\left(16 \mathrm{mmol} \mathrm{L}^{-1}\right)$ solution. An increase in $\alpha \mathrm{TOC}$ can be explained by the generation of molecular oxygen and chlorine and their chemical, electrochemical and photochemical reactions, whose result is the generation of radicals. For further measurements current intensity 0.3 A was selected due to the only slight increase in $\alpha \mathrm{TOC}$ for higher values of current intensity.

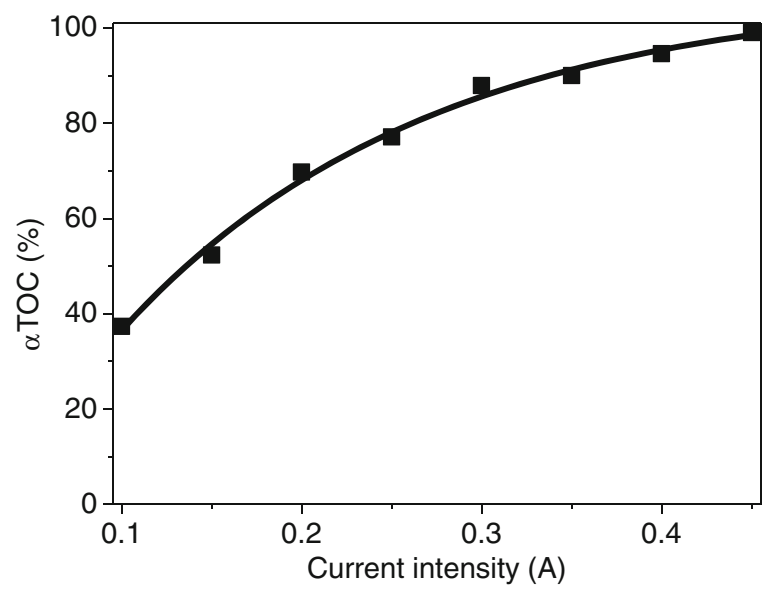

Fig. 9 The change of $\alpha$ TOC vs. current intensity after a 2-hphotoelectrochemical reaction of SCS $\left(2 \mathrm{mmol} \mathrm{L}^{-1}\right)$ in $\mathrm{NaCl}$ solution (16 mmol L ${ }^{-1}$ ), $V=160 \mathrm{~mL}$, UV lamp $15 \mathrm{~W}, \lambda=254 \mathrm{~nm}, \mathrm{pH}=7$ 
Fig. 10 Ion chromatograms recorded before and after photoelectrochemical process of $\mathrm{NaClO}_{4}$ solution $\left(100 \mathrm{mmol} \mathrm{L}^{-1}\right), V=160 \mathrm{~mL}$, UV lamp $15 \mathrm{~W}, \lambda=254 \mathrm{~nm}$, current intensity of $0.3 \mathrm{~A}$, $\mathrm{pH}=7$

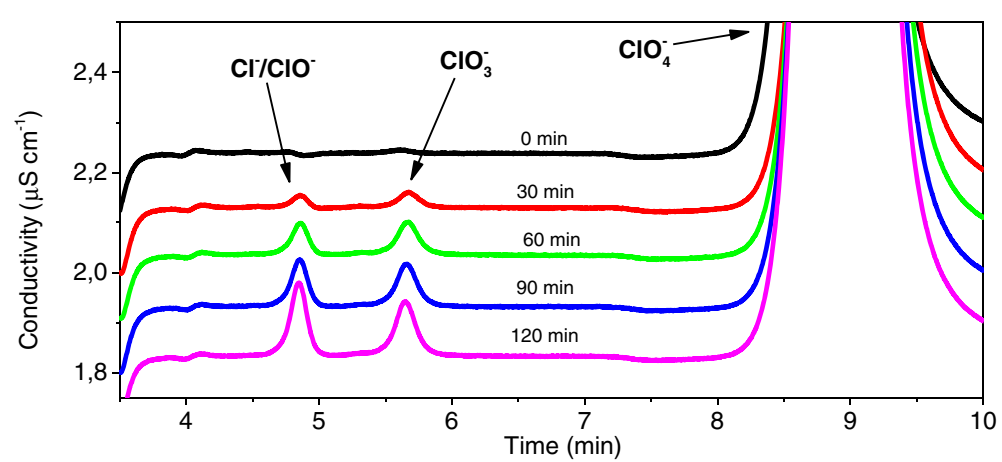

Basic electrolyte $\mathrm{NaClO}_{4}$ in the photoelectrochemical reaction with the use of $\mathrm{Ti} / \mathrm{TiO}_{2}$ and $\mathrm{RuO}_{2}$ anode and platinum cathode can undergo different reactions. Bokos and Horanyi (1993) as well as Lang and Horanyi (2003) proved that $\mathrm{ClO}_{4}{ }^{-}$ions may undergo reduction on the platinum electrode. They presented the mechanism of $\mathrm{ClO}_{4}{ }^{-}$reduction on a rhodium electrode stating that the reduction process begins with the adsorption of $\mathrm{ClO}_{4}{ }^{-}$ ions on the active sites of the metal surface and the $\mathrm{Cl}^{-}$ ions adsorb on the electrode, inhibiting the process of reduction (Lang et al. 2008). The standard potentials in relation to NHE of particular stages of $\mathrm{ClO}_{4}{ }^{-}$ions reduction are as follows (Lang et al. 2003):

$$
\begin{aligned}
& \mathrm{ClO}_{4}^{-}+2 \mathrm{H}^{+}+2 \mathrm{e}^{-} \rightleftarrows \mathrm{ClO}_{3}{ }^{-}+\mathrm{H}_{2} \mathrm{O}, \mathrm{E}^{\mathrm{o}}=1.19 \mathrm{~V}(23) \\
& \mathrm{ClO}_{3}{ }^{-}+2 \mathrm{H}^{+}+\mathrm{e}^{-} \rightleftarrows \mathrm{ClO}_{2}+\mathrm{H}_{2} \mathrm{O}, \mathrm{E}^{\mathrm{o}}=1.15 \mathrm{~V}
\end{aligned}
$$

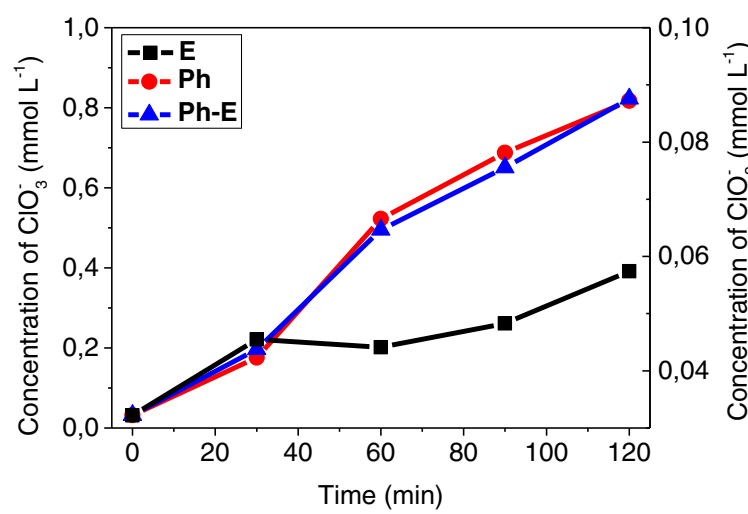

Fig. 11 The change of the concentration of $\mathrm{ClO}_{3}{ }^{-}$ions vs. reaction time after: $E$ electrochemical process (right axis), $\mathrm{Ph}$ photochemical process, and $P h-E$ photoelectrochemical process (left axis) in $\mathrm{NaClO}_{4}\left(100 \mathrm{mmol} \mathrm{L}^{-1}\right)$ solution, $V=160 \mathrm{~mL}$, UV lamp $15 \mathrm{~W}, \lambda=254 \mathrm{~nm}$, current intensity of $0.3 \mathrm{~A}, \mathrm{pH}=7$
$\mathrm{ClO}_{2}+\mathrm{e}^{-} \rightleftarrows \mathrm{ClO}_{2}^{-}, \mathrm{E}^{\mathrm{o}}=0.93 \mathrm{~V}$

$\mathrm{ClO}_{2}+\mathrm{H}^{+}+\mathrm{e}^{-} \rightleftarrows \mathrm{HClO}_{2}, \mathrm{E}^{\mathrm{o}}=1.27 \mathrm{~V}$

$\mathrm{HClO}_{2}+2 \mathrm{H}^{+}+2 \mathrm{e}^{-} \rightleftarrows \mathrm{HClO}+\mathrm{H}_{2} \mathrm{O}, \mathrm{E}^{\mathrm{o}}=1.64 \mathrm{~V}$

$\mathrm{HClO}+\mathrm{H}^{+}+2 \mathrm{e}^{-} \rightleftarrows \mathrm{Cl}^{-}+\mathrm{H}_{2} \mathrm{O}, \mathrm{E}^{\mathrm{o}}=1.50 \mathrm{~V}$

$\mathrm{NaClO}_{4}$ undergoes photochemical decomposition and the products contain mostly oxygen, a small amount of chloride ions and chlorine oxides (Pai Verneker and Maycock 1968). All the products of $\mathrm{NaClO}_{4}$ cathodic reaction as well as its photodecomposition can be subjected to electrochemical, photochemical and chemical transformations. Chloride ion formed on the anode as a result of $\mathrm{NaClO}_{4}$ reduction or just present in the solution undergoes oxidation to $\mathrm{Cl}_{2}$ and is submitted to chemical and photochemical changes according to the reactions (Kang et al. 2006; Neta et al. 1988; Huie et al. 1991):

$$
\begin{aligned}
& \mathrm{Cl}_{2}+\mathrm{h} v \rightarrow 2 \mathrm{Cl}^{\circ}, \mathrm{E}^{\mathrm{o}}=2.4 \mathrm{~V} \\
& \mathrm{Cl}^{\circ}+\mathrm{Cl}^{-} \rightarrow \mathrm{Cl}_{2}^{--}, \mathrm{E}^{\mathrm{o}}=2.1 \mathrm{~V} \\
& \mathrm{HClO}+\mathrm{h} v \rightarrow{ }^{\circ} \mathrm{OH}+\mathrm{Cl}^{\bullet}, \mathrm{E}^{\mathrm{o}}=2.7 \mathrm{~V}, \mathrm{E}^{\mathrm{o}}=2.4 \mathrm{~V}(31) \\
& \mathrm{ClO}^{-}+\mathrm{h} v \rightarrow \mathrm{Cl}^{\circ}+\mathrm{O}^{-}(253.7 \text { and } 313 \mathrm{~nm}), \mathrm{E}^{\mathrm{o}}=2.4 \mathrm{~V}(32) \\
& \mathrm{ClO}_{2}{ }^{-}+\mathrm{h} v \rightarrow \mathrm{ClO}^{-}+\mathrm{O}^{-}(253.7 \text { and } 313 \mathrm{~nm}), \mathrm{E}^{\mathrm{o}}=1.41 \mathrm{~V}(33)
\end{aligned}
$$$$
\mathrm{ClO}_{3}{ }^{-}+\mathrm{H}_{2} \mathrm{O}+\mathrm{h} v \rightarrow \mathrm{ClO}_{2}{ }^{\cdot}+\mathrm{OH}+\mathrm{OH}^{-},
$$$$
\mathrm{E}^{\mathrm{o}}=0.94 \mathrm{~V}, \mathrm{E}^{\mathrm{o}}=1.8 \mathrm{~V}
$$ 


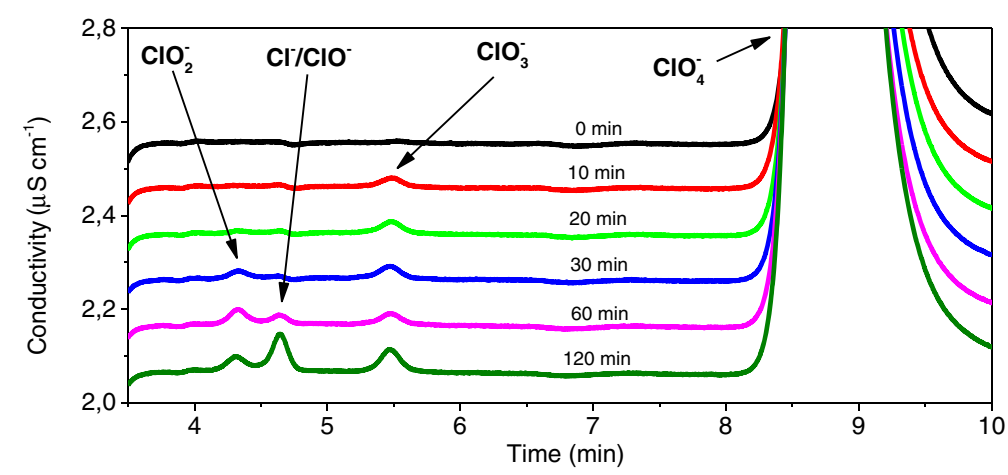

Fig. 12 Ion chromatograms recorded before and after photoelectrochemical reaction of SCS $\left(2 \mathrm{mmol} \mathrm{L}^{-1}\right)$ in $\mathrm{NaClO}_{4}$ solution $\left(100 \mathrm{mmol} \mathrm{L}^{-1}\right), V=160 \mathrm{~mL}$, UV lamp $15 \mathrm{~W}, \lambda=254 \mathrm{~nm}$, current intensity of $0.3 \mathrm{~A}, \mathrm{pH}=7$

To prove the presence of the products of electroreduction and photodecomposition of $\mathrm{NaClO}_{4}$, electrochemical, photochemical, and photoelectrochemical reactions of $\mathrm{NaClO}_{4}$ were carried out. Figure 10 presents an example of ion chromatogram of the products of the photoelectrochemical reaction of $\mathrm{NaClO}_{4}$ solution. The chromatograms show that a slight amount of $\mathrm{ClO}_{3}{ }^{-}$and $\mathrm{Cl}^{-}$or $\mathrm{ClO}^{-}$ions is formed. The method used failed to separate $\mathrm{Cl}^{-}$and $\mathrm{ClO}^{-}$ions. In the photochemical and photoelectrochemical reaction of $\mathrm{NaClO}_{4}$ the same ions are formed and their concentration is comparable. The concentration of $\mathrm{ClO}_{3}{ }^{-}$ions, which were formed in $\mathrm{NaClO}_{4}$ electrolyte during electrochemical, photochemical, and photoelectrochemical reactions, shows Fig. 11.

Perchlorate can be generated as a final product of the photochemical reaction of aqueous solutions containing $\mathrm{NaClO}, \mathrm{NaClO}_{2}$, and $\mathrm{NaClO}_{3}$ salts exposed to UV radiation. However, it can only be formed if the concentration of precursors $\left(\mathrm{NaClO}, \mathrm{NaClO}_{2}\right.$, and $\left.\mathrm{NaClO}_{3}\right)$ is higher than $1,000 \mathrm{mg} \mathrm{L}^{-1}$. Perchlorate is a thermodynamically stable molecule in comparison with $\mathrm{NaClO}$, $\mathrm{NaClO}_{2}$, and $\mathrm{NaClO}_{3}$ (Kang et al. 2006). Therefore, one can conclude that under experimental conditions, $\mathrm{ClO}_{3}{ }^{-}$ and $\mathrm{Cl}^{-}$or/and $\mathrm{ClO}^{-}$are the final products of photoelectrochemical changes of $\mathrm{NaClO}_{4}$.

The substrate underwent photoelectrochemical reaction in $\mathrm{NaClO}_{4}$ solution. It was proved that as in the basic electrolyte, along with the reaction time, the concentration of $\mathrm{ClO}_{3}{ }^{-}$and $\mathrm{Cl}^{-}$or $\mathrm{ClO}^{-}$ions as well as $\mathrm{ClO}_{2}{ }^{-}$ions in the case of photoelectrochemical reaction increases. Exemplary chromatograms of the solution after the photoelectrochemical reaction of substrate in $\mathrm{NaClO}_{4}$ solution are presented in Fig. 12.
The results obtained during the photoelectrochemical degradation of $\mathrm{SCS}$ in $\mathrm{NaClO}_{4}$ solution are presented in Fig. 13. The effect of this reaction is a rapid decrease in the concentration of the substrate, an increase in the content of $\mathrm{SO}_{4}{ }^{2-}$ ions and the increase in the $\alpha \mathrm{TOC}$ up to about $35 \%$. Also, the increase in the rate of $\alpha$ TOC after about 90 minutes is observed. The increase in the concentration of $\mathrm{ClO}_{3}{ }^{-}$ions, particularly after an almost complete decay of the substrate in the electrolyte, is practically proportional to the increase in the content of $\mathrm{SO}_{4}{ }^{2-}$ ions as a product of substrate desulfonation and to the decline in the content of organic carbon.

Figure 14 presents the results of photoelectrochemical reaction of SCS in $\mathrm{NaClO}_{4}$ solution with an addition of $\mathrm{NaClO}\left(2 \mathrm{mmol} \mathrm{L}^{-1}\right)$. The addition of $\mathrm{ClO}^{-}$ions causes

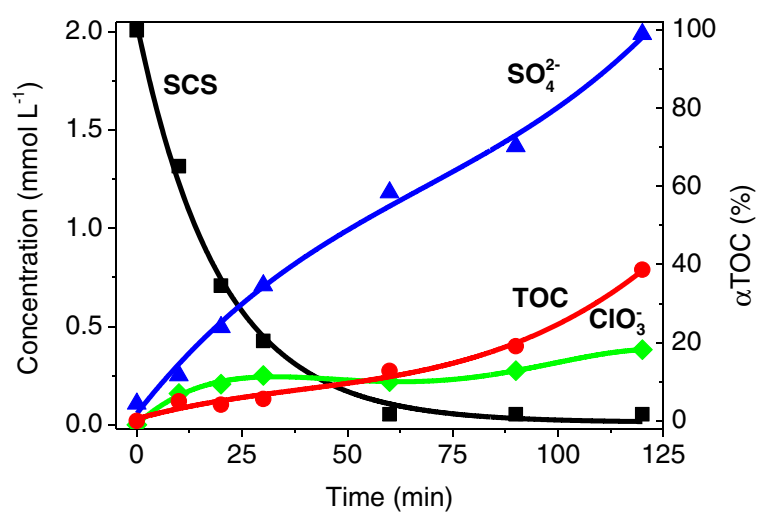

Fig. 13 The change of the concentration of SCS, $\mathrm{SO}_{4}{ }^{2-}, \mathrm{ClO}_{3}{ }^{-}$ (left axis), and $\alpha$ TOC (right axis) vs. time of photoelectrochemical reaction of SCS $\left(2 \mathrm{mmol} \mathrm{L}^{-1}\right)$ in $\mathrm{NaClO}_{4}$ solution $\left(100 \mathrm{mmol} \mathrm{L}^{-1}\right)$, $V=160 \mathrm{~mL}$, UV lamp $15 \mathrm{~W}, \lambda=254 \mathrm{~nm}$, current intensity of $0.3 \mathrm{~A}$, $\mathrm{pH}=7$ 


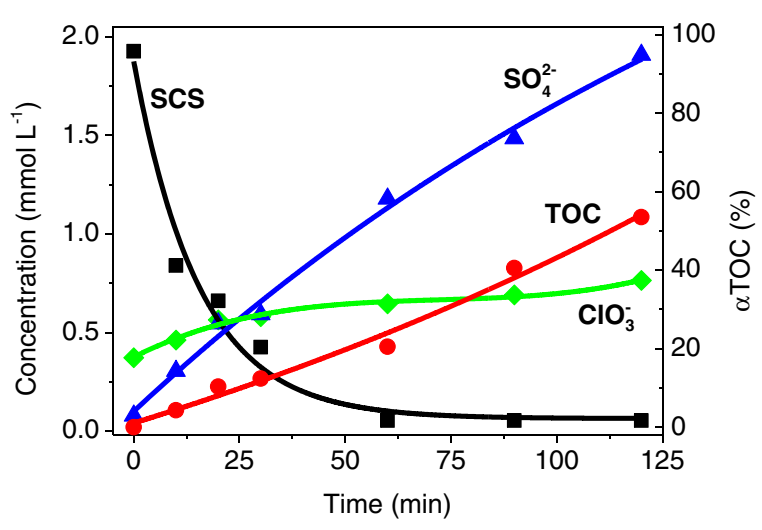

Fig. 14 The change of the concentration of $\mathrm{SCS}, \mathrm{SO}_{4}{ }^{2-}, \mathrm{ClO}_{3}{ }^{-}$ (left axis), and $\alpha \mathrm{TOC}$ (right axis) vs. time of photoelectrochemical reaction of SCS $\left(2 \mathrm{mmol} \mathrm{L}^{-1}\right)$ and $\mathrm{NaClO}\left(2 \mathrm{mmol} \mathrm{L}^{-1}\right)$ in $\mathrm{NaClO}_{4}$ solution $\left(100 \mathrm{mmol} \mathrm{L}^{-1}\right), V=160 \mathrm{~mL}$, UV lamp $15 \mathrm{~W}, \lambda=254 \mathrm{~nm}$, current intensity of $0.3 \mathrm{~A}, \mathrm{pH}=7$

the increase of the $\alpha \mathrm{TOC}$ from 35 to $55 \%$ after 120 minutes of the reaction, and its acceleration after 55 minutes. The added $\mathrm{NaClO}$ solution contained also $\mathrm{ClO}_{3}{ }^{-}$ions in an amount of about $0.372 \mathrm{mmol} \mathrm{L}^{-1}$. However, the amount of $\mathrm{ClO}_{3}{ }^{-}$ions formed in the reaction is similar to that in pure $\mathrm{NaClO}_{4}$. Therefore, it was tested whether the addition of $\mathrm{ClO}_{3}{ }^{-}$ions to $\mathrm{NaClO}_{4}$ solution could result in the increase in the reaction products, connected with the formation of hydroxyl radicals, according to the reaction 35 (Kang et al. 2006).

$$
\mathrm{ClO}_{3}{ }^{-}+\mathrm{H}_{2} \mathrm{O}+\mathrm{h} v \rightarrow \mathrm{ClO}_{2}{ }^{\cdot}+{ }^{\cdot} \mathrm{OH}+\mathrm{OH}^{-}
$$

It was stated that during the photoelectrochemical reaction of SCS in $\mathrm{NaClO}_{4}$ solution with the addition of $\mathrm{ClO}_{3}{ }^{-}\left(2 \mathrm{mmol} \mathrm{L}^{-1}\right)$ of ions, the same $\alpha \mathrm{TOC}$ as in pure $\mathrm{NaClO}_{4}$ solution was obtained. It proves that the presence of $\mathrm{ClO}_{3}{ }^{-}$ions in the photoelectrochemical reaction is insignificant. Another photoelectrochemical

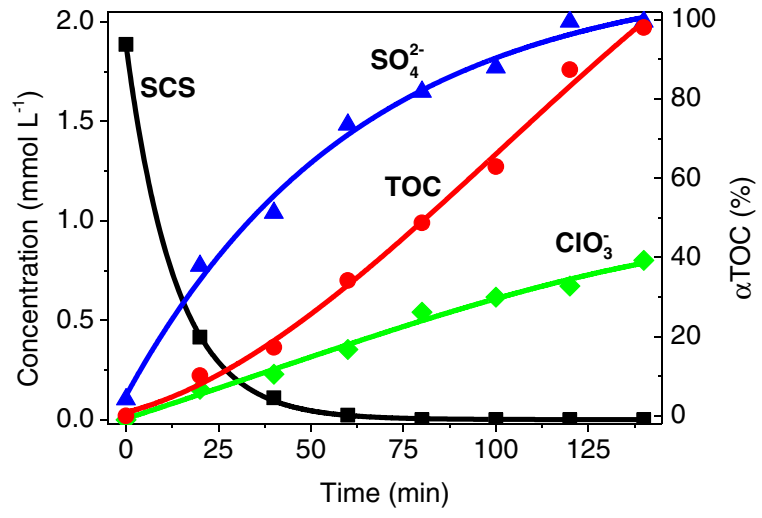

Fig. 16 The change of the concentration of $\mathrm{SCS}, \mathrm{SO}_{4}{ }^{2-}, \mathrm{ClO}_{3}{ }^{-}$(left axis), and $\alpha \mathrm{TOC}$ (right axis) vs. time of photoelectrochemical reaction of SCS $\left(2 \mathrm{mmol} \mathrm{L}^{-1}\right)$ in $\mathrm{NaCl}$ solution $\left(16 \mathrm{mmol} \mathrm{L}^{-1}\right), V=160 \mathrm{~mL}$, UV lamp $15 \mathrm{~W}, \lambda=254 \mathrm{~nm}$, current intensity of $0.3 \mathrm{~A}, \mathrm{pH}=7$

reaction of SCS was carried out in $\mathrm{NaCl}\left(16 \mathrm{mmol} \mathrm{L}^{-1}\right)$ solution. Figure 15 presents ion chromatograms characterizing a decrease in SCS, accompanied by the increase in $\mathrm{SO}_{4}{ }^{2-}$ and $\mathrm{ClO}_{3}{ }^{-}$content in this reaction. As expected, the reaction of photoelectrochemical degradation of SCS in $\mathrm{NaCl}\left(16 \mathrm{mmol} \mathrm{L}^{-1}\right)$ solution leads to even better results (Fig. 16). After 120 minutes, a $90 \%$ of $\alpha$ TOC is achieved and the acceleration of the reaction is observed after about 40 minutes. At the same time the concentration of the $\mathrm{ClO}_{3}{ }^{-}$ions formed is almost two times higher than in the solution described previously. Similarly as in previous reactions, along with the increase of $\mathrm{ClO}_{3}{ }^{-}$concentration, an increase in $\alpha \mathrm{TOC}$ and the amount of arising $\mathrm{SO}_{4}{ }^{2-}$ ions is observed. This fact indicates a cyclic use of the resulting radicals in the SCS degradation.

The concentration of $\mathrm{ClO}_{3}{ }^{-}$ions as a final product of radicals transformation in the presence of SCS is always smaller than in the electrolyte. An example of the change
Fig. 15 Ion chromatograms recorded before and after photoelectrochemical reaction of SCS $\left(2 \mathrm{mmol} \mathrm{L}^{-1}\right)$ in $\mathrm{NaCl}$ solution

$\left(16 \mathrm{mmol} \mathrm{L}^{-1}\right), V=160 \mathrm{~mL}$, UV lamp $15 \mathrm{~W}, \lambda=254 \mathrm{~nm}$, current intensity of $0.3 \mathrm{~A}$, $\mathrm{pH}=7$

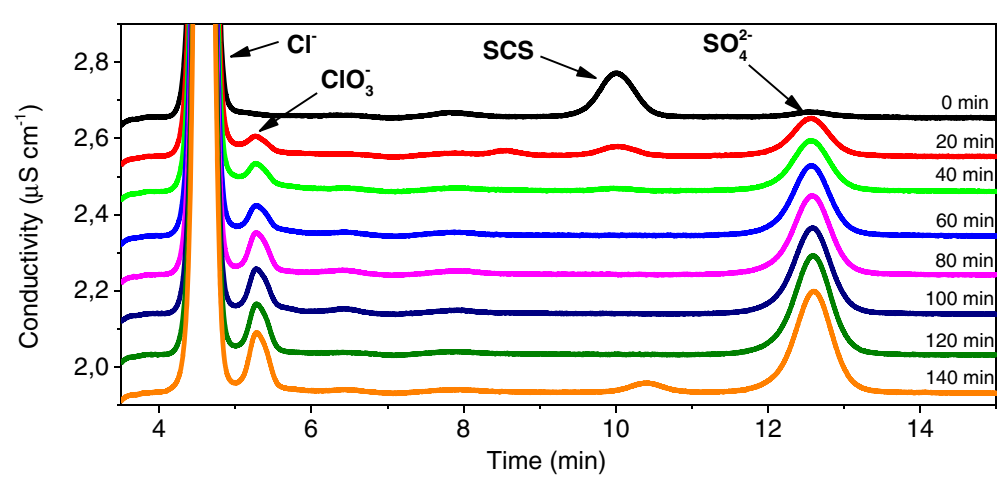




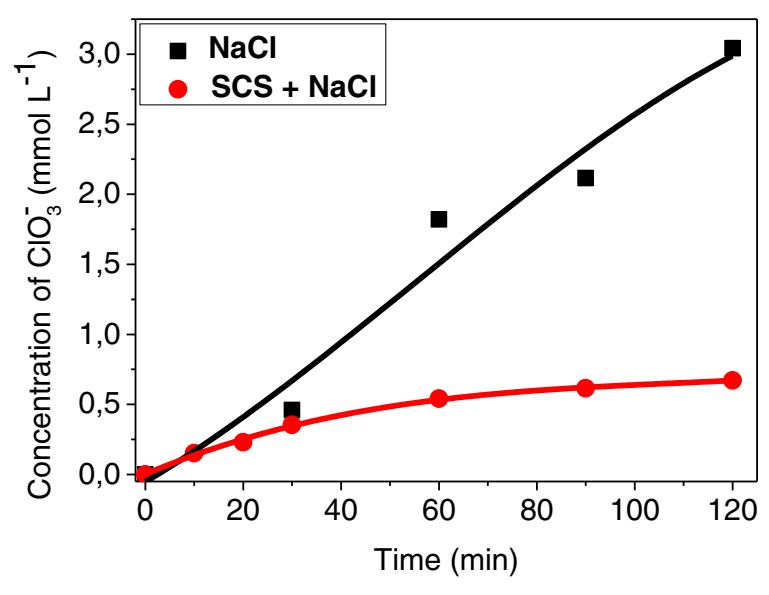

Fig. 17 The change of the concentration of $\mathrm{ClO}_{3}{ }^{-}$ions vs. time of photoelectrochemical reaction of SCS $\left(2 \mathrm{mmol} \mathrm{L}^{-1}\right)$ in $\mathrm{NaCl}$ solution $\left(16 \mathrm{mmol} \mathrm{L}^{-1}\right)$ and $\mathrm{NaCl}$ solution $\left(16 \mathrm{mmol} \mathrm{L}^{-1}\right), V=160 \mathrm{~mL}, \mathrm{UV}$ lamp $15 \mathrm{~W}, \lambda=254 \mathrm{~nm}$, current intensity of $0.3 \mathrm{~A}, \mathrm{pH}=7$

in $\mathrm{ClO}_{3}{ }^{-}$concentration during the photoelectrochemical reaction in $\mathrm{NaCl}$ and $\mathrm{SCS}$ in $\mathrm{NaCl}$ solutions is presented in Fig. 17.

\subsection{Optimization of Photoelectrochemical Process with Brandon Method}

The mathematical model of the process was constructed using the Brandon method (Kukiełka 2002; Trusov et al. 2002). This method was used to determine the relationship between $\alpha$ TOC conversion and parameters which influence the photoelectrochemical process of SCS degradation. The order of the variables in the equation influences the precision of the results; $t$ - time and $\mathrm{i}$ - current were used in the optimization process, the solution $16 \mathrm{mmol} \mathrm{L}^{-1} \mathrm{NaCl}$ was assumed in all experiments. It is necessary to build a model by a consistent decrease in the number of statistically significant and less significant factors. Using the Brandon method of multiple regression a mathematical dependence of $\alpha \mathrm{TOC}(\mathrm{y})$ on the reaction time (t) and current (i) was determined. The form of the equation is as follows, Eq. (36)

$$
\begin{aligned}
\mathrm{y}= & 0.95\left(-410^{-5} \mathrm{t}^{3}+9.810^{-3} \mathrm{t}^{2}+710^{-3} \mathrm{t}+5.63\right) \\
& \left(-510^{-6} \mathrm{i}^{2}+510^{-3} \mathrm{i}+710^{-2}\right)
\end{aligned}
$$

Based on this dependence, the parameters $t$ and $i$, which allowed maximum $\alpha$ TOC conversion, were determined. For the parameters $\mathrm{t}=135 \mathrm{~min}$ and $\mathrm{i}=350 \mathrm{~mA}$, $\alpha$ TOC achieved $99.5 \%$ at energy consumption about $1.2 \mathrm{kWh}$ per $\mathrm{g}$ of TOC removed. Energy consumption was calculated by the adding of energy consumption during photochemical process (UV lamp $15 \mathrm{~W}$ ) to energy consumption during electrochemical process (voltage was $10 \mathrm{~V}, \mathrm{i}=0.35 \mathrm{~A}$ and $\mathrm{t}=2.25 \mathrm{~h}$ ) and divided by weight of TOC removed. The dependence of $\alpha$ TOC vs. reaction time and current is shown in Fig. 18.

Fig. 18 The change of $\alpha \mathrm{TOC}$ vs. current and reaction time after the photoelectrochemical process of SCS $\left(2 \mathrm{mmol} \mathrm{L}^{-1}\right)$ in $\mathrm{NaCl}$ solution $\left(16 \mathrm{mmol} \mathrm{L}^{-1}\right), V=160 \mathrm{~mL}$, UV lamp $15 \mathrm{~W}, \lambda=254 \mathrm{~nm}$, $\mathrm{pH}=7$

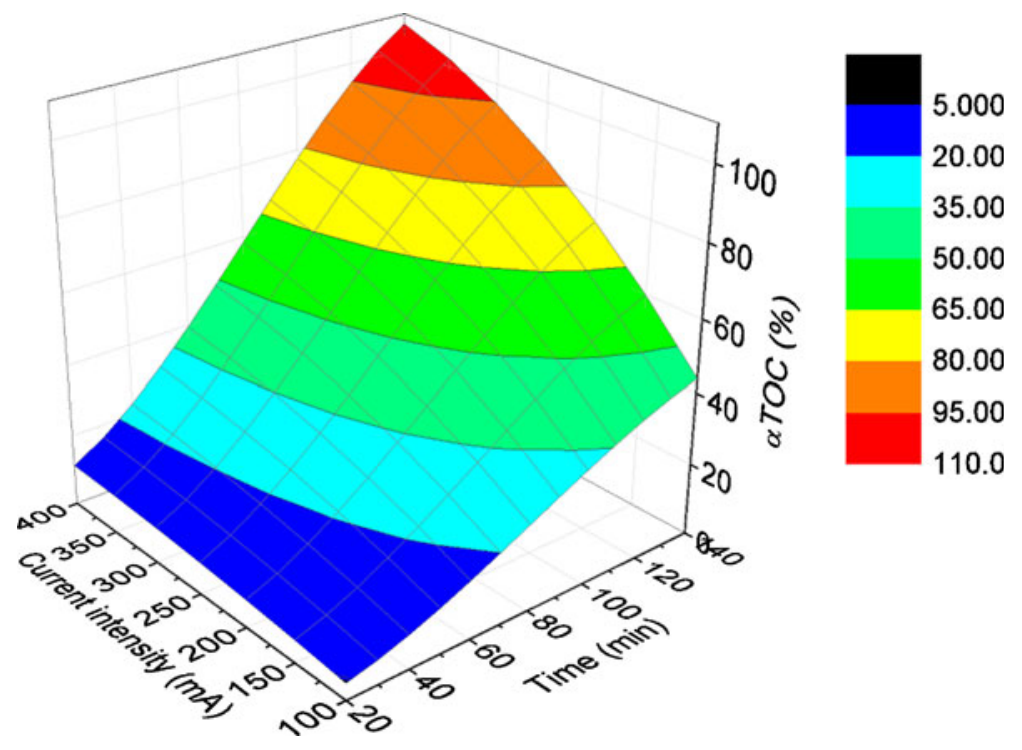




\section{Conclusions}

SCS is reduced on mercury electrode in three steps $\left(\mathrm{E}_{1 / 2}=\right.$ $-1.25,-1.35$, and $-1.42 \mathrm{~V}$ vs. SCE) in the potential range lower than the potential at which hydrogen evolution started. The substrate in acetonitrile is oxidized in two stages $\left(\mathrm{E}_{1 / 2}=2\right.$ and $2.25 \mathrm{~V}$ vs. SCE) on the platinum electrode. SCS is adsorbed on applied electrodes surface during the electrooxidation and electreduction process. Adsorption and a high potential of oxidation and reduction cause low mineralization of substrate during the electrochemical reaction (about $5 \%$ ).

It was proved that during electrochemical, photochemical and photoelectrochemical reactions, $\mathrm{NaClO}_{4}$ decomposes forming mainly $\mathrm{Cl}^{-}$and $\mathrm{ClO}_{3}{ }^{-}$ions. It was concluded that the main cause of synergy in the photoelectrochemical destruction of SCS in $\mathrm{NaClO}_{4}$ solution is its photochemical decomposition leading to the generation of $\mathrm{Cl}^{\circ}, \mathrm{ClO}^{\circ-}, \mathrm{ClO}_{2}{ }^{--}$, and $\mathrm{ClO}_{3}{ }^{--}$radicals. The increase in the $\alpha \mathrm{TOC}$ is proportional to the increase in the concentration of added $\mathrm{Cl}^{-}$ions into $\mathrm{NaClO}_{4}$ solution which is caused by the increase in the number of radicals resulting from the electrochemical, photochemical and photoelectrochemical reactions of $\mathrm{Cl}^{-}$ions and their inhibitory effect on $\mathrm{ClO}_{4}{ }^{-}$reaction on the electrode surface. The photoelectrochemical mineralization of the substrate in $\mathrm{NaCl}$ solution at the concentration of $16 \mathrm{mmol} \mathrm{L}^{-1}$ is comparable with the efficiency of the reaction in $\mathrm{NaClO}_{4}$ solution containing more than $8 \mathrm{mmol} \mathrm{L}^{-1}$ of $\mathrm{NaClO}$. Total mineralization of SCS was achieved in the photoelectrochemical reactor with an immersion UV lamp $15 \mathrm{~W}$ in the period of 135 minutes and current intensity of $350 \mathrm{~mA}$. Under these conditions the energy consumption was about $1.2 \mathrm{kWh}$ per $\mathrm{g}$ of TOC removed.

Open Access This article is distributed under the terms of the Creative Commons Attribution License which permits any use, distribution, and reproduction in any medium, provided the original author(s) and the source are credited.

\section{References}

Bakos, I., \& Horányi, G. (1993). Study of the relationship between voltammetric behaviour and electrocatalytic activity in the reduction of $\mathrm{ClO}_{4}{ }^{-}$ions at platinized platinum electrodes. Journal of Electroanalytical Chemistry, 347(1-2), 383-391.

Bhat, M., \& Gaikar, V. G. (1999). Characterization of interaction between butyl benzene sulfonates and cetyl trimethylammonium bromide in mixed aggregate systems. Langmuir, 15(14), 47404751.

Bhat, M., \& Gaikar, V. G. (2000). Characterization of interaction between butylbenzene sulfonates and cetyl pyridinium chloride in a mixed aggregate system. Langmuir, 16(4), 1580-1592.

Brown, G. M. (1986). The reduction of chlorate and perchlorate ions at an active titanium electrode. Journal of Electroanalytical Chemistry, 198(2), 319-300.

Catanho, M., Malpass, G. R. P., \& Motheo, A. J. (2006). Photoelectrochemical treatment of the dye reactive red 198 using DSA ${ }^{\circledR}$ electrodes. Applied Catalysis B: Environmental, 62(3-4), 193-200.

Feng, Y., Smith, W. D., \& Boton, J. (2007). Photolysis of aqueous free chloride species $\left(\mathrm{HClO}\right.$ and $\left.\mathrm{OCl}^{-}\right)$with $254 \mathrm{~nm}$ ultraviolet light. Journal of Environmental Engineering, 6(3), 277284.

Gaikar, V. G., \& Phatak, P. V. (1999). Selective solubilization of isomers in hydrotrope solution o-/p-chlorobenzoic acids and $\mathrm{o}^{-} / \mathrm{p}$ nitro anilines. Separation Science and Technology, 34(3), 439-459.

Guo, H. (1993). Time-dependent quantum dynamical study of the photodissociation of HClO. The Journal of Physical Chemistry, 97(11), 2602-2608.

Harano, Y., \& Smith, J. M. (1968). Tubular flow photoreactor for complex, nonochain kinetics. AICHE Journal, 14(4), 584-591.

Hasegawa, K., \& Neta, P. (1978). Rate constants and mechanism of reaction of chloride $\left(\mathrm{Cl}_{2}{ }^{-}\right)$radicals. American Chemical Society, 82(8), 854-857.

Hepel, M., \& Luo, J. (2001). Photoelectrochemical mineralization of textile diazo dye pollutants using nanocrystalline $\mathrm{WO}_{3}$ electrodes. Electrochimica Acta, 47(5), 729-740.

Huie, R. E., Clifton, C. L., \& Neta, P. (1991). Electron transfer reaction rates and equlibria of the carbonate and sulfate radicals ions. International Journal of Radiation Applications and Instrumentation. Part C. Radiation Physics and Chemistry, 38(5), 477-481.

Kang, N., Anderson, T. A., \& Jackson, W. J. (2006). Photochemical formation of perchlorate from aqueous oxychlorine anions. Analytica Chimica Acta, 567(1), 48-56.

Khadilkar, B. M., Gaikar, V. G., \& Chitnavis, A. A. (1995). Aqueous hydrotrope solution as a safer medium for microwave enhanced hantzsch dihydropyridine ester synthesis. Tetrahedron Letters, 36(44), 8083-8086.

Kim, D. H., \& Anderson, M. A. (1994). Photoelctrocatalytic degradation of formic acid using a porous $\mathrm{TiO}_{2}$ thin-film electrode. Environmental Science and Technology, 28(3), 479-483.

Kimura, M., \& Ogata, Y. (1983). Photo-oxidation some aromatic sulfuric acids with alkaline hypochlorite. Bulletin of the Chemical Society of Japan, 56(2), 471-473.

Kozłowski, A., Kąkol, B., Kaczorowski, M., Tomassi, P., Chróst, S., Chmielowiec, U., et al. (1990). Low concentration bath for shiny nickel electroplating. Patent PL, 286184, A1.

Kukiełka, L. (2002). The bases of engineering study (pp. 114122). PWN Warszawa.

Lang, G. G., \& Horanyi, G. (2003). Some interesting aspects of the catalytic and electrocatalytic reduction of perchlorate ions. Journal of Electroanalytical Chemistry, 552, 197-211.

Lang, G., Ujvari, M., \& Horanyi, G. (2003). On the reduction of $\mathrm{ClO}_{4}{ }^{-}$ions in the course of metal dissolution in $\mathrm{HClO}_{4}$ solutions. Corrosion Science, 45(1), 1-5. 
Lang, G. G., Sas, N. S., Ujvari, M., \& Horanyi, G. (2008). The kinetics of the electrochemical reduction of perchlorate ions on rhodium. Electrochimica Acta, 53(25), 7436-7444.

Mollna, M. J., Ishiwata, T., \& Molina, L. (1980). Production of $\mathrm{OH}$ from photolysis of $\mathrm{HOCl}$ at $307-309 \mathrm{~nm}$. The Journal of Physical Chemistry, 84(8), 821-826.

Neta, P., Huie, R. E., \& Ross, A. B. (1988). Rate constants for reactions of inorganic radicals in aqueous solution. Journal of Physical and Chemical Reference Data, 17(3), 258-270.

Noorjahan, M., Pratap Reddy, M., Durga Kumari, V., Lavédrine, B., Boule, P., \& Subrahmanyam, M. (2003). Photocatalytic degradation of $\mathrm{H}$-acid over a novel $\mathrm{TiO}_{2}$ thin film fixed bed reactor and in aqueous suspensions. Journal of Photochemistry and Photobiology A: Chemistry, 156(13), 179-187.

Osiewała, L., Socha, A., Perek, A., \& Rynkowski, J. (2012). Photoelectrochemical decomposition of sodium xylenesulfonate in the solution of $\mathrm{NaClO}_{4}$ with $\mathrm{NaClO}$ addition. Przemyst Chemiczny, 91(2), 206-209.

Pai Verneker, V. R., \& Maycock, D. J. N. (1968). The photochemical decomposition of silver perchlorate. The Journal of Physical Chemistry, 72(8), 2798-2801.

Pelegrini, R., Peralta-Zamora, P., de Andrade, A. R., Reyes, J., \& Durán, N. (1999). Electrochemically assisted photocatalytic degradation of reactive dyes. Applied Catalysis B: Environmental, 22(2), 83-90.

Rahman, M. Y. A., Salleh, M. M., Talib, I. A., Yahaya, M., \& Ahmad, A. (2007). Current transport mechanism and photovoltaic properties photoelectrochemical cells of $\mathrm{ITO} / \mathrm{TiO}_{2} /$
PVC-LiClO 4 graphite. Current Applied Physics, 7(4), 446449.

Socha, A., Chrzescijanska, E., \& Kusmierek, E. (2005). Electrochemical and photoelectrochemical treatment of 1aminonaphthalene-3,6-disulfonic acid. Dyes and Pigments, 67(1), 71-75.

Stanton, K., Tibazarwa, C., Certa, H., Greggs, W., Hillebold, D., Jovanovich, L., et al. (2010). Environmental risk assessment of hydrotropes in the United States, Europe, and Australia. Integrated Environmental Assessment and Management, 6(1), 155-163.

Trusov, N. V., Grin, G. I., \& Prezhdo, V. V. (2002). Industrial Monitoring As a Source of Valuable Information on the Unit Process. Theoretical Foundations of Chemical Engineering, 36(5), 505-510.

Xiao, S., Qu, J., Zhao, X., Liu, H., \& Wan, D. (2009). Electrochemical process combined with UV light irradiation synergistic degradation of ammonia in chloride-containing solutions. Water Research, 43(5), 1432-1440.

Yalkowsky, S. H. (1981). Techniques of solubilization of drugs. New York: Dekker, M.

YanQing, C., ZuCheng, W., \& YuQiong, L. (2007). Hydroxyl radical electrochemically generated with water as the complete atom source and its environmental application. Chinese Science Bulletin, 52(10), 1432-1435.

Zhang, W., An, T., Cui, M., Sheng, G., \& Fu, J. (2005). Effects of anions on the photocatalytic and photoelectrocatalytic degradation of reactive dye in a packed-bed reactor. Journal of Chemical Technology and Biotechnology, 80(2), 223-229. 